\title{
IMPACT OF DIETARY SUPPLEMENTATION OF PREBIOTICS ON THE GROWTH PERFORMANCE AND IMMUNITY IN BROILERS FED LOW PROTEIN DIETS
}

\author{
NAGLAA S.K. IBRAHIM, ABDEL-BASET N.S. AHMED \\ AND GHADA S.E. ABDEL-RAHEEM \\ Department of Nutrition and Clinical Nutrition, Faculty of Veterinary Medicine, \\ Assiut University, Egypt.
}

Received: 5 September 2021; Accepted: 30 October 2021

\begin{abstract}
The current study was conducted to find out the influence of feeding broilers on low protein diets supplemented with prebiotic. Growth performance, carcass traits, muscle cholesterol, triglycerides, chemical composition, blood parameters and immune response of broilers were evaluated. A total number of 68 birds' one- day old broiler chicks (Ross 308) randomly distributed into 4 equal groups each of 17 chicks. The first group (control) was fed the basal $(100 \% \mathrm{NRC} \mathrm{CP})$ diet free from prebiotic. The other three groups (T2, T3 and T4) were fed on low protein diets $(95,90 \& 85 \%$ of NRC requirements, respectively) and supplemented with prebiotic at level of $0.1 \%$. The results showed that, birds in the second group had significantly higher live body weight, feed conversion, and dressing percentages. Supplementation of prebiotic had no significant effects on relative weight of liver, gizzard and immune organs. Reduction in the relative weight of abdominal fat pad in all prebiotic treated groups. There were significant reduction $(\mathrm{P}<0.05)$ in the meat cholesterol, triglycerides and fat mass of broiler breast and thigh, while protein content was significantly $(\mathrm{P}<0.05)$ increased in all prebiotic treated groups. A numerical increased in antibody titre in birds in the second and third groups. Birds in the second group had the best economic feed efficiency. It could be concluded that adding prebiotic to broiler diets low in protein $(95,90$ and $85 \%$ of NRC) has a beneficial effect on growth parameters, carcass traits, economic value in addition to healthy and nutritious poultry products for consumers.
\end{abstract}

Key words: Prebiotic, Low protein diet, Growth Performance, Immunity, and Broiler.

\section{INTRODUCTION}

The issue that poultry scientists and industry face is to provide an acceptable amount of poultry meat in the most efficient

Corresponding author: NAGLAA S.K. IBRAHIM

E-mail address: naglaasalah@vet.aun.edu.eg

Present address: Department of Nutrition and Clinical Nutrition, Faculty of Veterinary Medicine, Assiut University, Egypt. manner possible (Yadav and Jha, 2019), which can be accomplished in part by using certain feed additives. Antibiotic have been utilized in chicken feed for a long time as a growth stimulant to help balance the gut microbial flora, enhance overall performance, and stop certain intestinal pathologies (Khan and Iqbal 2016). However, due to the emergence of antibioticresistant microorganisms the European Commission (EC) decided to restrict the advertising, commercialization, and usage of 
antibiotics as growth stimulants in diet as of January 1, 2006 (Gadde et al., 2017). Prebiotics, probiotics, essential oils, and plant extracts are now being researched by the poultry industry in the hopes of keeping chicken intestines healthy and promoting immune system and performance (Wang et al., 2016).

Prebiotics are well-defined as non-digestible food ingredient that have a favourable effect on the host by encouraging the growth and/or activating the metabolism of one or a limited number of health-promoting bacteria in the intestines, thus having a beneficial impact in the host's microbial balance (Fallah et al., 2013). In general, Prebiotics can be fermented in the intestines by healthpromoting bacteria to produce lactic acid, short-chain fatty acids, or antibacterial compounds like bacteriocine against harmful bacteria (Bogusławska-Tryk et al., 2012). Pathogen colonization could be reduced by oligosaccharides and monosaccharides inhibiting pathogen receptor sites on epithelial cell surfaces (Pourabedin and Zhao, 2015).

Mannan oligosaccharides (MOS), a prebiotic produced from yeast cell walls, is one of these alternatives (Chacher et al., 2017). This indigestible sugar performs a wide range of tasks which includes selectively enhance the development and proliferation of native Bifidobacteria and Lactobacilli in the hindgut, suppressing the action of putrefactive or dangerous bacteria and resulting in reduced levels of harmful fermentation products in the GIT (Samanta et al., 2013), increased villus height and decreased crypt depth (Yang et al., 2009), modulated immune response (Khalaji et al., 2011), and improved broiler's growth performance in terms of weight gain and feed conversion (Žikic et al., 2011, kamran et al., 2013, Hussein et al., 2020 and Rehman et al., 2020).

Another commercial prebiotic active component, beta-glucan, has been shown to improve innate immunity and body growth in broilers (Chae et al., 2006, Huff et al., 2006 and Shendare et al., 2008). The usage of $\beta$-glucans or MOS to improve broiler performance has been well documented and has been linked to increased innate immune function (Wang et al., 2016).

Ingredients in feed, especially protein and energy sources, are the most expensive aspects of poultry nutrition (Wijtten et al., 2004). Poultry require a lot of protein in their diet, and this nutrient has a significant impact on their performance. Due to excessive nitrogen excretion and the high expense of dietary protein sources, the use of low protein diets (LPD) in chicken nutrition has gained considerable interest in recent years (Ravangard et al., 2017). So, the aim of this research is to see how prebiotic supplementation affect protein utilization of broilers fed low protein diets and to mitigate the detrimental effects of these diets.

\section{MATERIALS AND METHODS}

The current work was carried out at the Applied Nutrition Research Unit (ANRU), Teaching Veterinary Hospital, Faculty of Veterinary Medicine, Assuit University.

AGRIMOS Prebiotics is a feed ingredient produced from a high quality saccharomyces cervices yeast cell wall. AGRIMOS is a high source of Mannan-Oligosaccharides (MOS) and $\beta$-Glucans). LALLEMAND SAS Co. Provided the commercial product AGRIMOS ${ }^{\circledR}$, which was supplied by Egavet Co., Egypt.

\section{Birds, housing and feeding:}

A total number of 68 birds one- day old unsexed broiler chicks (Ross 308) were obtained from local commercial source, weighed and randomly distributed to 4 equal groups each of 17 chicks. The initial average weight of the experimental chicks was $(40.29 \pm 0.45 \mathrm{~g})$. Birds in all groups were housed in floor pens and kept under the same management system and environmental conditions. Birds were fed 
according to two phases feeding program: starter diet $(0-21$ days $)$ and grower-finisher diet (22-42 days). The first group was provided a prebiotic-free basal diet (100 percent NRC CP) as a control group. The other three groups were fed on low protein diets $(95,90 \& 85 \%$ of NRC requirements) enriched with $0.1 \%$ prebiotic. Birds were fed ad-libitum on the respective diets (Table 1) and given free access to fresh water throughout the experimental period.

\section{Feed ingredients analysis:}

The dietary ingredients were chemically analyzed to determine dry matter (DM), ether extract (EE), crude protein $(\mathrm{CP})$, and ash, while nitrogen free extract was computed using the Association of Official Analytical Chemists' procedures (AOAC, 2011). Metabolizable energy content of the feed ingredients and experimental diets were calculated based on chemical composition cited by NRC (1994).

\section{Data Collection and Sampling: Performance indicators:}

Performance parameters including body weight, body weight gain and feed intake were recorded weekly.

\section{Carcass Traits:}

At the end of the experimental period, three birds were randomly taken from each group weighed and slaughtered to complete bleeding after a night fasting. The weight of dressed carcass (the weight of slaughtered birds after removal feathers, head, feet and viscera but including all the edible offal's) was recorded. The absolute weights of some internal organs including (liver, gizzard and heart), abdominal fat pad and immune organs (bursa, spleen and thymus) were recorded. Immune organs and abdominal fat pad weights were expressed as relative weight of live body weight.

\section{Meat parameters:}

\section{Muscle cholesterol and triglycerides:}

Using reagent kits that are commercially available (Wako pure chemical industries, Ltd., Tokyo, japan), total cholesterol and triglyceride values in breast and thigh meat samples were measured enzymatically as described previously (Bligh and Dyer .1959, Naeemi et al., 1995 and Afrose et al., 2009).

\section{Meat chemical composition:}

Meat samples from breast and thigh of the slaughtered birds in all the experimental groups were prepared (carefully minced and homogenized) and chemically analyzed for moisture, crude protein, ether extract and ash following AOAC (2011) official methods.

\section{Blood collection and analysis:}

At day 42, three birds were chosen at random from each group and blood samples were taken from the wing vein. The blood samples were centrifuged for 15 minutes at $4000 \mathrm{rpm}$ and the sera were transferred into aseptically vials and saved at $-20{ }^{\circ} \mathrm{C}$ until further analysis. As previously published, the log NDV serum antibody titer was measured using the Haemagglutination Inhibition (HI) assay. (OIE, 2013). Using a spectrophotometer and commercial test kits (Spectrum, Cairo, Egypt), total protein, albumin, globulin, triglycerides, and cholesterol levels were measured.

\section{Economical evaluation:}

Total feed cost, total production cost, body weight price, net income, and economic feed efficiency were computed at the end of the experiment, according to Hassan and El Shoukary (2019) and Omar et al. (2019).

\section{Statistical analysis:}

Using SPSS 20 statistical software (SPSS Inc., Chicago, IL, USA), all data have been analyzed using one-way analysis of variances (ANOVA) followed by Duncan's test, www.spss.com 
Table 1: Composition and energy value of the experimental diets.

\begin{tabular}{|c|c|c|c|c|c|c|c|c|}
\hline \multirow[b]{2}{*}{ Ingredient (\%) } & \multicolumn{4}{|c|}{ Starter diets $(0-21 d)$} & \multicolumn{4}{|c|}{ Grower Finisher diets (22-42 d) } \\
\hline & $\begin{array}{l}100 \% \\
\text { NRC }\end{array}$ & $\begin{array}{l}95 \% \\
\text { NRC }\end{array}$ & $\begin{array}{l}90 \% \\
\text { NRC }\end{array}$ & $\begin{array}{l}85 \% \\
\text { NRC }\end{array}$ & $\begin{array}{l}100 \% \\
\text { NRC }\end{array}$ & $\begin{array}{l}95 \% \\
\text { NRC }\end{array}$ & $\begin{array}{l}90 \% \\
\text { NRC }\end{array}$ & $\begin{array}{l}85 \% \\
\text { NRC }\end{array}$ \\
\hline $\begin{array}{l}\text { Yellow corn, } \\
\text { ground }\end{array}$ & 48.95 & 53.37 & 57.83 & 62.21 & 60.94 & 64.77 & 68.64 & 72.37 \\
\hline Soybean meal & 39.85 & 36.02 & 32.18 & 28.40 & 30.31 & 26.98 & 23.66 & 20.40 \\
\hline Sunflower oil & 7.25 & 6.50 & 5.74 & 5.00 & 5.20 & 4.57 & 3.89 & 3.30 \\
\hline $\begin{array}{l}\text { Limestone, } \\
\text { ground }\end{array}$ & 1.71 & 1.75 & 1.75 & 1.76 & 1.68 & 1.70 & 1.70 & 1.72 \\
\hline $\begin{array}{c}\text { Mono calcium } \\
\text { phosphate }\end{array}$ & 1.38 & 1.39 & 1.42 & 1.45 & 1.00 & 1.01 & 1.05 & 1.07 \\
\hline Common salt & 0.30 & 0.30 & 0.30 & 0.30 & 0.30 & 0.30 & 0.30 & 0.30 \\
\hline Premix* & 0.30 & 0.30 & 0.30 & 0.30 & 0.30 & 0.30 & 0.30 & 0.30 \\
\hline DL-methionine & 0.16 & 0.18 & 0.20 & 0.21 & 0.08 & 0.10 & 0.11 & 0.12 \\
\hline L-lysine & 0.10 & 0.19 & 0.28 & 0.37 & 0.19 & 0.27 & 0.35 & 0.42 \\
\hline Total & 100 & 100 & 100 & 100 & 100 & 100 & 100 & 100 \\
\hline \multicolumn{9}{|c|}{ Calculated chemical composition } \\
\hline $\mathrm{ME}(\mathrm{Kcal} / \mathrm{Kg})$ & $\begin{array}{c}3191.4 \\
7\end{array}$ & $\begin{array}{c}3191.5 \\
1\end{array}$ & 3191.76 & $\begin{array}{c}3192.1 \\
0\end{array}$ & $\begin{array}{c}3197.0 \\
9\end{array}$ & $\begin{array}{c}3198.8 \\
5\end{array}$ & $\begin{array}{c}3197.3 \\
1\end{array}$ & $\begin{array}{c}3200.0 \\
5\end{array}$ \\
\hline Crude protein $(\%)$ & 23.00 & 21.85 & 20.70 & 19.55 & 20.00 & 19.00 & 18.00 & 17.00 \\
\hline Calcium \% & 1.00 & 1.00 & 1.00 & 1.00 & 0.90 & 0.90 & 0.90 & 0.90 \\
\hline $\begin{array}{c}\text { Available } \\
\text { phosphorus } \%\end{array}$ & 0.45 & 0.45 & 0.45 & 0,45 & 0.35 & 0.35 & 0.35 & 0.35 \\
\hline Lysine \% & 1.30 & 1.30 & 1,30 & 1,30 & 1.16 & 1.16 & 1.16 & 1.16 \\
\hline Methionine \% & 0.50 & 0.50 & 0.50 & 0.50 & 0.38 & 0.38 & 0.38 & 0.38 \\
\hline $\mathrm{EE} \%$ & 8.80 & 8.13 & $\overline{7.45}$ & 6.79 & 6.97 & 6.41 & 5.80 & 5.28 \\
\hline $\mathrm{CF} \%$ & 2.83 & 2.75 & 2.67 & 2.60 & 2.66 & 2.59 & 2.52 & 2.45 \\
\hline
\end{tabular}

*Vitamines and minerals mixture (Multi Vita Co.): Each $3 \mathrm{~kg}$ contains: Vit. A, 12000000 IU; Vit. D3, 4000000 IU; Vit. E, 50000 mg; Vit. k3, 4000 mg; Vit. B1, 5000 mg; Vit.B2, 8000 mg; Vit. B6, 5000 mg; Vit. B12, 35 mg; Vit. C, 450 mg; Niacin, 70000 mg; Methionine, 3000 mg; Pantothenic acid , 20000 mg ; Folic acid 1000 mg; Biotin, 250 mg; Magnésium, 100000 mg; Copper, 15000 mg; Iron, $50000 \mathrm{mg}$; Zinc, $50000 \mathrm{mg}$; Cobalt, $250 \mathrm{mg}$; iodine $1500 \mathrm{mg}$ and Selenium $250 \mathrm{mg}$.

\section{RESULT}

\section{Growth performance:}

Inclusion of prebiotic to low protein broilers diet $(95 \%$ of NRC) (T2) increased the body weight and body weight gain significantly $(\mathrm{P}<0.05)$ compared with control (T1). While the addition of prebiotic to low protein broilers diets ( 90 and $85 \%$ of NRC) had no significant $(\mathrm{P}>0.05)$ effect on body weight and body weight gain in comparison with the control (Tables 2 and 3 ).

Concerning cumulative feed intake during starter period (0-3 w), feed consumption of chicks fed diets containing $(95,90$ and $85 \%$ protein of NRC (T2, T3 and T4) was nearly the same as showed in table (4). While the feed intake numerically decreased among all prebiotic treated groups during growing period (4-6w). In comparison with control group, adding prebiotics decreased the feed conversion ratio by $9.66 \%$ in $\mathrm{T} 2$ and $3.41 \%$ in T3. Conversely, inclusion of prebiotic to low protein diet containing $85 \%$ of NRC (T4) slightly increased the feed conversion ratio by $1.14 \%$ compared with the control one as presented in Table (4).

\section{Carcass traits:}

Table (5) summarizes the dressing percentages and relative organ weights for the various experimental groups. Inclusion of prebiotic to diet have $95 \%$ and $90 \%$ of 
NRC protein improved hot carcass\%, eviscerated carcass $\%$ and dressing percent. However, adding of prebiotic to $85 \%$ NRC protein diet (T4) not significantly $(\mathrm{P}>0.05)$ affected the measured parameters. Prebiotic addition had no significant effect on relative weight of liver and gizzard. There were no significant effect on the relative weight of heart in broilers in the second and third groups, while the broiler feed $85 \%$ NRC protein showed an increased in the relative weight of heart. Reduction in the relative weight of abdominal fat pad in all treated groups compared with the control was observed. Concerning the effect of prebiotic on the relative weights of immune organs of broilers fed different protein levels, there were no significant $(\mathrm{P}>0.05)$ effect on spleen, thymus and bursa relative weights were observed.

\section{Meat parameters:}

Results in table (6) revealed the addition of prebiotic to 95,90 and $85 \%$ protein of NRC requirements diets decreased significantly $(\mathrm{P}<0.05)$ the cholesterol and triglyceride contents of broiler breast and thigh meat compared with the control (T1).The cholesterol content decreased by $6.24 \%$, $11.58 \%$ and $15.82 \%$ of breast meat and by $11.35 \%, 12.71 \%$ and $17.79 \%$ of thigh meat of broiler fed 95\%, 90\% and 85\% NRC protein diets, respectively than the control. Triglycerides content was decreased by $13.39 \%, 19.95 \%$ and $25.55 \%$ of breast meat and by $15.71 \%, 18.47 \%$ and $23.15 \%$ of thigh meat of broiler fed $95 \%, 90 \%$ and $85 \%$ NRC protein diet, respectively than the control.

Data in Table (7) indicated that supplementation of prebiotic to $95 \%, 90 \%$ and $85 \%$ NRC protein diets showed no significant $(\mathrm{P}>0.05)$ differences in dry matter and ash contents of broiler breast and thigh meat among all the treatment groups including the control one. However, the fat content was significantly $(\mathrm{P}<0.05)$ decreased, while protein content of broiler breast and thigh meat significantly $(\mathrm{P}<0.05)$ increased. The fat content was significantly decreased by $20.4 \%, 28.57 \%$ and $34.69 \%$ of breast meat and by $16.42 \%, 19.40 \%$ and $26.86 \%$ of thigh meat for broiler fed 95, 90 and $85 \%$ NRC protein, respectively than control one.

\section{Blood parameters:}

Supplementation of prebiotic showed no significant differences in the level of serum total protein, albumin, globulin and $\mathrm{A} / \mathrm{G}$ ratio among all prebiotic treated groups and control one. However, serum cholesterol content and triglyceride numerically decreased in all treated groups.

The obtained data in Table (9) showed no significant differences in the antibody titre of Newcastle between different experimental groups at day 42 of age.

\section{Economic analysis:}

Regarding to economical evaluation, addition of prebiotic to diets containing 95, 90 and $85 \%$ of NRC protein requirements lowered the feed and total production costs in comparison with control as shown in table (10).

Broilers fed a $95 \%$ of NRC protein diet had the highest average economic efficiency value of $86.01 \%$, followed by birds fed a 90 $\%$ NRC supplemented diet $(76.41 \%)$ and 85 $\%$ NRC supplemented diet (74.22). According to the income-outcome analysis, the birds fed prebiotic with $95 \%$ NRC protein diet had the highest relative economic feed efficiency, followed by birds fed on prebiotic with $90 \%$ and $85 \%$ NRC protein diet, respectively. 
Table 2: Weekly body weight development (g) of broilers fed different experimental diets.

\begin{tabular}{ccccc}
\hline Groups & Control group & \multicolumn{3}{c}{ Prebiotic groups } \\
\cline { 2 - 5 } Period (week) & $\mathbf{T 1}$ & $\mathbf{T 2}$ & $\mathbf{T 3}$ & T4 \\
\hline Initial & $39.28 \pm 1.05$ & $40.43 \pm 0.86$ & $40.61 \pm 0.94$ & $40.89 \pm 0.77$ \\
\hline $\mathbf{1}$ & $137.10 \pm 2.67$ & $141.03 \pm 3.14$ & $139.62 \pm 2.20$ & $135.32 \pm 4.16$ \\
\hline $\mathbf{2}$ & $367.47 \pm 7.26^{\mathrm{b}}$ & $402.15 \pm 10.81^{\mathrm{a}}$ & $357.69 \pm 8.94^{\mathrm{b}}$ & $369.13 \pm 13.01^{\mathrm{b}}$ \\
\hline $\mathbf{3}$ & $755.60 \pm 14.62^{\mathrm{b}}$ & $852.69 \pm 24.59^{\mathrm{a}}$ & $734.46 \pm 20.54^{\mathrm{b}}$ & $735.53 \pm 25.31^{\mathrm{b}}$ \\
\hline $\mathbf{4}$ & $1225.40 \pm 25.64^{\mathrm{b}}$ & $1376.69 \pm 45.27^{\mathrm{a}}$ & $1151.85 \pm 35.11^{\mathrm{b}}$ & $1190.93 \pm 41.44^{\mathrm{b}}$ \\
\hline $\mathbf{5}$ & $1805.00 \pm 30.52^{\mathrm{b}}$ & $2052.69 \pm 66.78^{\mathrm{a}}$ & $1789.31 \pm 52.22^{\mathrm{b}}$ & $1790.87 \pm 67.93^{\mathrm{b}}$ \\
\hline $\mathbf{6}$ & $2411.67 \pm 48.39^{\mathrm{ab}}$ & $2603.85 \pm 84.74^{\mathrm{a}}$ & $2374.62 \pm 76.89^{\mathrm{b}}$ & $2350.05 \pm 88.09^{\mathrm{b}}$ \\
\hline
\end{tabular}

Means within the same row with different superscripts are significantly different $(\mathrm{P}<0.05)$.

T1 (100\% NRC CP, no additives), T2 (95\% NRC CP + prebiotic), T3 (90\% NRC CP + prebiotic) and T4 (85\% NRC CP + prebiotic).

Table 3: Weekly and cumulative weight gain (g) of broilers during different experimental periods

\begin{tabular}{ccccc}
\hline \multirow{2}{*}{$\begin{array}{c}\text { Exp. } \\
\text { Period (week) }\end{array}$} & Control group & \multicolumn{3}{c}{ Prebiotic groups } \\
\cline { 2 - 5 } & T1 & T2 & T3 & T4 \\
\hline $\mathbf{0 - 1}$ & $97.82 \pm 1.67$ & $100.6 \pm 2.32$ & $99.01 \pm 1.29$ & $94.43 \pm 3.46$ \\
\hline $\mathbf{1 - 2}$ & $230.37 \pm 4.65^{\mathrm{b}}$ & $261.12 \pm 7.82^{\mathrm{a}}$ & $218.07 \pm 6.90^{\mathrm{b}}$ & $233.81 \pm 9.02^{\mathrm{b}}$ \\
\hline $\mathbf{2 - 3}$ & $388.13 \pm 8.35^{\mathrm{b}}$ & $450.54 \pm 14.13^{\mathrm{a}}$ & $376.77 \pm 11.97^{\mathrm{b}}$ & $366.40 \pm 13.72^{\mathrm{b}}$ \\
\hline $\mathbf{3 - 4}$ & $469.80 \pm 13.00^{\mathrm{b}}$ & $524.01 \pm 21.44^{\mathrm{a}}$ & $417.39 \pm 15.67^{\mathrm{cd}}$ & $455.40 \pm 17.14^{\mathrm{bc}}$ \\
\hline $\mathbf{4 - 5}$ & $579.60 \pm 11.78^{\mathrm{b}}$ & $676.00 \pm 26.82^{\mathrm{a}}$ & $637.46 \pm 20.20^{\mathrm{ab}}$ & $599.94 \pm 30.86^{\mathrm{b}}$ \\
\hline $\mathbf{5 - 6}$ & $606.67 \pm 20.58$ & $551.16 \pm 28.28^{\mathrm{b}}$ & $585.31 \pm 27.93$ & $559.18 \pm 27.01$ \\
\hline $\mathbf{0 - 3}$ & $716.32 \pm 13.72^{\mathrm{b}}$ & $812.27 \pm 23.76^{\mathrm{a}}$ & $693.85 \pm 19.63^{\mathrm{b}}$ & $694.65 \pm 24.57^{\mathrm{b}}$ \\
\hline $\mathbf{4 - 6}$ & $1656.07 \pm 36.60$ & $1751.15 \pm 62.18$ & $1640.16 \pm 56.98$ & $1614.52 \pm 63.69$ \\
\hline $\mathbf{0 - 6}$ & $2372.39 \pm 47.39^{\mathrm{ab}}$ & $2563.42 \pm 83.98^{\mathrm{a}}$ & $2334.01 \pm 75.97^{\mathrm{b}}$ & $2309.17 \pm 87.38^{\mathrm{b}}$ \\
\hline
\end{tabular}

Means within the same row with different superscripts are significantly different $(\mathrm{P}<0.05)$.

Table 4: Feed consumption (g / chick) and feed conversion indices of broilers during different experimental period intervals.

\begin{tabular}{|c|c|c|c|c|}
\hline \multirow{2}{*}{${ }_{\text {week }}$ Group } & \multirow{2}{*}{$\begin{array}{c}\text { Control group } \\
\text { T1 }\end{array}$} & \multicolumn{3}{|c|}{ Prebiotic groups } \\
\hline & & $\mathbf{T 2}$ & T3 & T4 \\
\hline \multicolumn{5}{|c|}{ Feed consumption (g / chick) } \\
\hline$(0-3)$ & 1044.17 & 1077.23 & 1010.78 & 1003.49 \\
\hline (4-6) & 3121.37 & 2989.84 & 2955.49 & 3117.90 \\
\hline$(0-6)$ & 4165.54 & 4067.06 & 3966.27 & 4121.39 \\
\hline \multicolumn{5}{|c|}{ Feed conversion } \\
\hline$(0-3)$ & 1.46 & 1.33 & 1.46 & 1.44 \\
\hline$(4-6)$ & 1.88 & 1.71 & 1.80 & 1.93 \\
\hline$(0-6)$ & 1.76 & 1.59 & 1.70 & 1.78 \\
\hline
\end{tabular}


Table 5: Carcass traits, abdominal fat pad and relative weight of immune organs of broilers fed different experimental diets

\begin{tabular}{lcccc}
\hline \multirow{2}{*}{ Item } & Control group & \multicolumn{3}{c}{ Prebiotic groups } \\
\cline { 2 - 5 } & T1 & T2 & T3 & T4 \\
\hline Pre-slaughter weight, $\mathbf{g}$ & $2418.33 \pm 20.28^{\mathrm{ab}}$ & $2545.00 \pm 25.66^{\mathrm{a}}$ & $2361.67 \pm 66.73^{\mathrm{b}}$ & $2311.67 \pm 48.68^{\mathrm{b}}$ \\
\hline Hot carcass, \% & $86.70 \pm 0.29^{\mathrm{ab}}$ & $87.43 \pm 0.34^{\mathrm{a}}$ & $87.57 \pm 0.10^{\mathrm{a}}$ & $85.46 \pm 0.85^{\mathrm{b}}$ \\
\hline Eviscerated carcass, \% & $70.59 \pm 1.31^{\mathrm{b}}$ & $74.32 \pm 1.22^{\mathrm{a}}$ & $71.42 \pm 0.14^{\mathrm{b}}$ & $70.18 \pm 1.18^{\mathrm{b}}$ \\
\hline Dressed carcass, \% & $74.58 \pm 1.32^{\mathrm{ab}}$ & $77.97 \pm 1.21^{\mathrm{a}}$ & $75.65 \pm 0.24^{\mathrm{ab}}$ & $74.23 \pm 1.16^{\mathrm{b}}$ \\
\hline Liver, \% & $2.14 \pm 0.07$ & $1.95 \pm 0.05$ & $2.23 \pm 0.13$ & $2.25 \pm 0.16$ \\
\hline Heart, \% & $0.49 \pm 0.04^{\mathrm{b}}$ & $0.45 \pm 0.01^{\mathrm{b}}$ & $0.51 \pm 0.01^{\mathrm{b}}$ & $0.60 \pm 0.02^{\mathrm{a}}$ \\
\hline Gizzard, \% & $1.38 \pm 0.04^{\mathrm{ab}}$ & $1.31 \pm 0.04^{\mathrm{ab}}$ & $1.49 \pm 0.09^{\mathrm{a}}$ & $1.23 \pm 0.05^{\mathrm{b}}$ \\
\hline Abdominal Fat, \% & $1.52 \pm 0.03^{\mathrm{a}}$ & $1.40 \pm 0.16^{\mathrm{a}}$ & $1.01 \pm 0.08^{\mathrm{b}}$ & $1.23 \pm 0.10^{\mathrm{ab}}$ \\
\hline Spleen, \% & $0.10 \pm 0.02$ & $0.10 \pm 0.01$ & $0.12 \pm 0.00$ & $0.10 \pm 0.01$ \\
\hline Thymus, \% & $0.42 \pm 0.02$ & $0.45 \pm 0.03$ & $0.41 \pm 0.04$ & $0.42 \pm 0.06$ \\
\hline Bursa, \% & $0.09 \pm 0.02$ & $0.11 \pm 0.02$ & $0.09 \pm 0.01$ & $0.09 \pm 0.01$ \\
\hline
\end{tabular}

Means within the same row with different superscripts are significantly different $(\mathrm{P}<0.05)$.

Table 6: Meat cholesterol and triglycerides content $(\mathrm{mg} / 100 \mathrm{~g})$ of broilers fed different experimental diets.

\begin{tabular}{lcccc}
\hline \multirow{2}{*}{ Items } & Groups & Control group & \multicolumn{3}{c}{ Prebiotic groups } \\
\cline { 2 - 5 } & T1 & T2 & T3 & T4 \\
\hline The breast meat & & & & \\
\hline Cholesterol & $79.98 \pm 0.29^{\mathrm{a}}$ & $74.99 \pm 0.30^{\mathrm{b}}$ & $70.72 \pm 0.29^{\mathrm{c}}$ & $67.33 \pm 0.20^{\mathrm{d}}$ \\
\hline Triglyceride & $95.60 \pm 0.20^{\mathrm{a}}$ & $82.80 \pm 0.24^{\mathrm{b}}$ & $76.53 \pm 0.25^{\mathrm{c}}$ & $71.17 \pm 0.11^{\mathrm{d}}$ \\
\hline The thigh meat & & & & \\
\hline Cholesterol & $108.19 \pm 0.20^{\mathrm{a}}$ & $95.91 \pm 0.11^{\mathrm{b}}$ & $94.44 \pm 0.18^{\mathrm{c}}$ & $88.94 \pm 0.47^{\mathrm{d}}$ \\
\hline Triglyceride & $112.26 \pm 0.17^{\mathrm{a}}$ & $94.62 \pm 0.21^{\mathrm{b}}$ & $91.52 \pm 0.23^{\mathrm{c}}$ & $86.27 \pm 0.19^{\mathrm{d}}$ \\
\hline
\end{tabular}

Means within the same row with different superscripts are significantly different $(\mathrm{P}<0.05)$.

Table 7: Meat composition (\%) of broilers in the different experimental groups.

\begin{tabular}{|c|c|c|c|c|}
\hline \multirow{2}{*}{ Items } & \multirow{2}{*}{$\begin{array}{c}\text { Control group } \\
\text { T1 } \\
\end{array}$} & \multicolumn{3}{|c|}{ Prebiotic groups } \\
\hline & & $\overline{T 2}$ & $\overline{T 3}$ & $\overline{T 4}$ \\
\hline \multicolumn{5}{|c|}{ Chemical composition (\%) of the breast meat: } \\
\hline DM & $26.19 \pm 1.21$ & $28.43 \pm 1.00$ & $27.81 \pm 1.30$ & $26.72 \pm 0.58$ \\
\hline CP (\%DM) & $76.00 \pm 1.73^{b}$ & $81.80 \pm 2.00^{\mathrm{a}}$ & $84.50 \pm 2.07^{\mathrm{a}}$ & $86.00 \pm 3.18^{\mathrm{a}}$ \\
\hline EE (\%DM) & $4.90 \pm 0.17^{\mathrm{a}}$ & $3.90 \pm 0.12^{\mathrm{b}}$ & $3.50 \pm 0.12^{\mathrm{bc}}$ & $3.20 \pm 0.12^{c}$ \\
\hline $\operatorname{Ash}(\% \mathrm{DM})$ & $3.27 \pm 0.57$ & $4.58 \pm 0.38$ & $3.90 \pm 0.23$ & $3.63 \pm 0.37$ \\
\hline \multicolumn{5}{|c|}{ Chemical composition (\%) of the thigh meat: } \\
\hline$\overline{D M}$ & $26.34 \pm 1.15$ & $26.38 \pm 1.5$ & $27.97 \pm 1.15$ & $29.47 \pm 2.6$ \\
\hline CP (\%DM) & $74.90 \pm 1.73^{\mathrm{b}}$ & $80.20 \pm 2.3^{\mathrm{a}}$ & $82.60 \pm 2.05^{\mathrm{a}}$ & $84.70 \pm 1.73^{\mathrm{a}}$ \\
\hline EE (\%DM) & $6.70 \pm 0.06^{\mathrm{a}}$ & $5.60 \pm 0.12^{\mathrm{b}}$ & $5.40 \pm 0.12^{\mathrm{b}}$ & $4.90 \pm 0.17^{\mathrm{c}}$ \\
\hline $\operatorname{Ash}(\% \mathrm{DM})$ & $4.15 \pm 0.58$ & $4.10 \pm 0.53$ & $4.27 \pm 0.58$ & $4.98 \pm 0.29$ \\
\hline
\end{tabular}

Means within the same row with different superscripts are significantly different $(\mathrm{P}<0.05)$. 
Table 8: Blood biochemical parameters of broilers in the different experimental groups.

\begin{tabular}{lcccc}
\hline \multirow{2}{*}{ Item } & Control group & \multicolumn{3}{c}{ Prebiotic groups } \\
\cline { 2 - 5 } & T1 & T2 & T3 & T4 \\
\hline Total protein (g/dl) & $2.47 \pm 0.33$ & $2.20 \pm 0.00$ & $2.43 \pm 0.12$ & $2.40 \pm 0.20$ \\
\hline Albumin $(\mathbf{g} / \mathbf{d l})$ & $1.13 \pm 0.07$ & $1.17 \pm 0.00$ & $1.17 \pm 0.09$ & $1.10 \pm 0.06$ \\
\hline Globulin $(\mathbf{g} / \mathbf{d l})$ & $1.33 \pm 0.33$ & $1.10 \pm 0.00$ & $1.27 \pm 0.07$ & $1.30 \pm 0.15$ \\
\hline A/G ratio & $0.83 \pm 0.07$ & $1.00 \pm 0.00$ & $0.93 \pm 0.09$ & $0.83 \pm 0.09$ \\
\hline Cholesterol (mg/dl) & $89.25 \pm 0.55$ & $83.90 \pm 7.33$ & $81.50 \pm 0.86$ & $80.80 \pm 3.12$ \\
\hline Triglycerides (mg/dl) & $77.11 \pm 6.46^{\mathrm{a}}$ & $64.46 \pm 3.42^{\mathrm{ab}}$ & $67.06 \pm 5.64^{\mathrm{ab}}$ & $60.83 \pm 0.50^{\mathrm{b}}$ \\
\hline
\end{tabular}

Means within the same row with different superscripts are significantly different $(\mathrm{P}<0.05)$.

Table 9: Humeral antibody titers post Newcastle vaccination of broiler in the different experimental groups

\begin{tabular}{ccccc}
\hline day & Groups & Control group & \multicolumn{3}{c}{ Prebiotic groups } \\
\cline { 2 - 5 } & $\mathbf{T 1}$ & $\mathbf{T 2}$ & $\mathbf{T 3}$ & $\mathbf{T 4}$ \\
\hline \multirow{2}{*}{ 42day } & $5.00 \pm 0.00$ & $6.00 \pm 1.15$ & $6.00 \pm 0.00$ & $4.67 \pm 0.33$
\end{tabular}

Means within the same row with different superscripts are significantly different $(\mathrm{P}<0.05)$.

Table 10: Economical evaluation of the experimental diets.

\begin{tabular}{lcccc}
\hline \multirow{2}{*}{ Items } & Control group & \multicolumn{3}{c}{ Prebiotic groups } \\
\cline { 2 - 5 } & T1 & T2 & T3 & T4 \\
\hline Total feed cost (L.E)* & 28.20 & 27.50 & 25.88 & 25.97 \\
\hline Total production cost (L.E) & 42.70 & 42.00 & 40.38 & 40.47 \\
\hline Body weight (Kg/bird) & 2.41 & 2.60 & 2.37 & 2.35 \\
\hline Total revenue & 72.35 & 78.12 & 71.24 & 70.50 \\
\hline Net revenue & 29.65 & 36.12 & 30.86 & 30.03 \\
\hline Economic feed efficiency (\%) & 69.43 & 86.01 & 76.41 & 74.22 \\
\hline Relative economic feed efficiency & 100 & 123.87 & 110.05 & 106.89 \\
\hline
\end{tabular}

* LE= Egyptian pound according to price at the experimental time.

\section{DISCUSSION}

\section{Growth performance:}

Results of growth performance parameters supported by the findings of kamran et al. (2013) and Rehman et al. (2020) who found that, supplementation of diets with MOS increased broiler live body weight and gain. In addition, Chae et al. (2006) and Huff et al. (2006) recorded that, the significant improvement in body weight and weight gain of broilers fed on diets supplemented with B-glucan may be due to the enhancement in innate immune response (Bozkurt et al. 2012). Similar result found by Hooge et al. (2013) and Abdel-Hafeez et al. (2017) who found a significant improvement in body weight and gain of broilers fed on prebiotic supplemented diets. On the other hand, Midilli et al. (2008), Corrigan et al. (2011) and Salehimanesh et al. (2016) suggested that, the dietary supplementation of MOS and B-glucan did not affect body weight and gain of broiler. The addition of MOS \& B-glucan had no significant effect on duck body weight and gain (Mahmoud et al., 2020). The inclusion of prebiotic improved the low level protein diet which gave the same effect of $100 \%$ NRC protein diet (control) on body weight and body weight gain. The positive effect of dietary inclusion of prebiotic might be 
attributed to the health of gut lining, which may be due to short chain fatty acids production, which provide the energy for intestinal epithelial cells (Ferket et al., 2005) and increased the partition of nutrients into other tissues of body (Ajuwon, 2016), enhance enzyme activity or provide a larger surface area for efficient nutrients absorption (Yang et al., 2009).

Regarding to feed intake, results were in line with the findings of Salianeh et al. (2011) who demonstrated decreased feed intake in broiler chickens as a result of dietary inclusion of prebiotic. In addition, Salehimanesh et al. (2016) demonstrated that, prebiotic at $0.9 \mathrm{~g} / \mathrm{kg}$ numerically decreased the feed intake of broiler chicks. Broilers fed the prebiotic were more effective at converting feed to body mass during the raising period. In general, improvements in feed conversion were attributed to stimulated growth of the beneficial microflora in the GIT induced by dietary supplementation of prebiotic as demonstrated by Cinar et al. (2009). These results agreed with the finding of Salianeh $e t$ al. (2011) who observed the addition of prebiotic decreased feed conversion ration significantly. In agreement with our results, a series of scientific reports (Žikic et al., 2011; Hooge et al., 2013 and Hussein et al., 2020) demonstrated that addition of prebiotics resulted in either a numerical or significant improvement in the feed efficiency. On the other hand, Baurhoo et al. (2009) and Salehimanesh et al. (2016) stated that, addition of prebiotic did not affect significantly the feed conversion ratio. Regarding the effect of crude protein levels ( $90 \%$ and $85 \%$ NRC CP diet), deleterious effects of low protein diet on FCR have been showed in some previous studies (Zeng et al., 2015; Ravangard et al., 2017 and Xie et al., 2017). In addition, Ospina-Rojas et al. (2014) demonstrated that, birds fed on low protein diets recorded significantly worse feed conversion than those fed on control diets during starter and grower periods. Such effect on feed conversion ratio was not observed in the present study, this means that the addition of prebiotic improved the adverse effect of low protein diet.

\section{Carcass traits:}

The current data matched with the findings recorded by Park and Park (2011) and Sojoudi et al. (2012) who found significantly increased in dressing percentage and empty carcass percent. Also Abdel-Fattah and Fararh, (2009) demonstrated a slight improvement in dressing percentage in bird fed diets supplemented with MOS. While other studies Salehimanesh et al. (2016); Abdel-Hafeez et al. (2017) and Rehman et al. (2020) ) reported that, prebiotic seemed to have no significant impact on carcass parameters of broilers. As well as, nonsignificant effect in carcass characteristics due to the use of different protein levels have been reported in some previous studies ( Gheisari et al. (2015); Xie et al. (2017) and Shao et al. (2018) ). Similarly, AbdelRaheem and Abd-Allah (2011) and Odefemi (2016) recorded that adding prebiotic to broiler had no significant effect on gizzard and liver relative weight. However, Sojoudi et al. (2012) and Abdel-Hafeez et al. (2017) reported that, the relative weight of liver and gizzard significantly increased by feeding prebiotic. There were no significant effect in the relative weight of heart in broilers fed $95 \%$ and $90 \% \mathrm{NRC}$, while the broiler feed 85\% NRC protein showed an increased in the relative weight of heart. Awad et al. (2014) explained the greater relative heart weight of broilers fed low protein diet by their worse body weight compared to other groups.

Results of immune organ weights came in accordance with those reported by Cox et al. (2010) who observed that, supplementation of $\beta$-glucan did not significantly affect relative immune organ weights. Also Sojoudi et al. (2012) demonstrated that broiler fed prebiotic $(0.1 \%, 0.15 \%, 0.2 \%)$ showed no significant difference between treatments in thymus weight, thymus percent, bursa fabricius weight and bursa fabricius percent $(\mathrm{P}>0.05)$, but there was a significant difference in spleen weight and 
spleen percent. Li et al. (2016) found that, yeast cell wall feeding had no effect on the relative weights of the thymus or the spleen $(\mathrm{P}>0.05)$. In contrast, Abdel-Raheem and Abd-Allah (2011) demonstrated that, there was a significant increase in the bursa and thymus absolute weights due to MOS supplementation of broilers.

The numerical decrease in the relative weight of abdominal fat pad is extremely fascinating and good for the customers. The positive effect of prebiotic has been showed to reduce the abdominal fat level as reported by Abdel-Hafeez et al. (2017) and Ilham et al. (2019). In terms of the impact of various crude protein levels on abdominal fat, the results showed that abdominal fat was significantly increased in low level crude protein diet (Zeng et al., 2015, DehghaniTafti and Jahanian, 2016 and Xie et al., 2017). Feeding with low protein diet stimulated lipogenesis in the birds' livers, causing in increased liver weight and, as a result, increased fat deposition in the abdomen (Swennen et al., 2006). However, in the current investigation, no such effect was reported, this means that, the addition of prebiotic improved the adverse effect of low protein diet.

\section{Meat parameters:}

There were a significant reduction $(\mathrm{P}<0.05)$ in the meat cholesterol, triglyceride and fat mass content of broiler breast and thigh meat of the prebiotics treated groups. Similar results were reported by Sutama et al. (2010), Ilham et al. (2019) and Okrathok and Khempaka (2020) who found that probiotic and prebiotic feed additives are able to decline the fat and cholesterol levels in the animals. The decreased in meat fat mass was consistent with some previous reports (Ooi and Liong (2010) and Weitkunat et al. (2015)).

Ilham et al. (2019) suggested that the decreasing of meat fat and cholesterol level in prebiotic supplemented birds may be related to the absorption process of bile acids and cholesterol from digestive tracts which depending on the food crude fiber content. Crude fiber of prebiotic binding with bile acids resulted in hindering the absorption of fat. Therefore, feces excretion with bile elements such as cholesterol was increased, and hence reducing abdomen fat (Akhadiarto, 2010). Wiryawan et al. (2005) stated that lactic acids bacteria produce organic acids which hinder the absorption of the bile acids and enhance their excretion from the birds body. When the level of the bile acids reduced, the body will depend on the cholesterol which came from bloods and tissues system in the creations of the bile acids. This cycle will lower the levels of cholesterol in the blood and meat.

An increase in CP content of broiler muscle may be attributed to low protein diet rather than prebiotic feeding. Gheisari et al. (2015) found the percentage of protein in female carcasses was significantly $(\mathrm{P}<0.05)$ lower in chicks fed on higher protein diets than other groups. Hai and Bláha (2000) and Kamran et al. (2008) also recorded lowering of dietary CP level had no adverse effect on carcass proteins. In contrast, Marcu et al. (2009) found that broiler fed high protein and energy levels, resulted in higher water and protein content and fat content was lower.

\section{Blood parameters:}

Our result confirming the earlier findings of Li et al. (2016), Abdel-Hafeez et al. (2017) and Mahmoud et al. (2017) who found that serum total protein, albumin and globulin of broilers did not significantly affected by prebiotic supplementation. Similar findings were reported by Mahmoud et al. (2020) who found the addition of prebiotic had no prominent effect on total protein, albumin and globulin. In addition, other studies (Taherpour et al., 2009, Abdel-Raheem and Abd-Allah, 2011 and Okrathok and Khempaka, 2020) demonstrated low serum cholesterol level as a result of prebiotic feeding. On the other hand, Abdel-Hafeez et al. (2017) and Hazrati et al. (2020) reported no significant $(\mathrm{P}<0.05)$ effect on serum cholesterol level. In agreement with our 
result, Yalçinkaya et al. (2008), Jahanian and Ashnagar (2015) and Hazrati et al. (2020) recorded that feeding prebiotic decreased serum triglycerides. In contrast, Kamran et al. (2010); Zeng et al. (2015) and Dehghani-Tafti and Jahanian (2016) found an increased in serum triglycerides level due to low protein diet. Birds fed a low-protein diet utilized carbohydrates as a source of energy rather than free fatty acids, resulting in an increase in plasma triglyceride content. Swennen et al. (2005) and Kamran et al. (2010).

The inclusion of prebiotic improved the post vaccination NDV antibody titers especially during the weeks when titers were decreasing. These findings are consistent with previous researchs (Zakeri and Kashefi, 2011, Mehdi and Hasan, 2012 and Salehimanesh et al., 2016) who observed an elevation in antibody titers against NDV as a result of MOS supplementation. Gao et al. (2008) found that YCW has a positive effect on the humeral immunity of broiler chicks, which is consistent with this study. Much of the mechanism underlying the immunomodulation caused by the MOS is yet unknown. One theory is that, the presence of microorganisms is recognized by immune cells in the gut-associated lymphoid tissue (GALT) by detecting molecules that are specific to pathogens named Pathogen Associated Molecular Patterns (PAMP). The yeast cell walls (MOS and B-glucan) considered as Pathogen Associated Molecular Patterns (Ballou, 1970), they bind to pattern-recognition receptors on a variety of GALT defense cells, triggering immunological responses (Mehdi and Hasan 2012). Huang et al. (2007) found that, inclusion of oligochitosan in the diet increased immunological response, as indicated by increased serum post vaccination NDV antibody titers, they came to the conclusion that prebiotics could improve bird immunity through a various mechanisms, including prevent pathogenic microbes from colonizing so these pathogens are still allowed to be given to immune cells as attenuated antigens, the active group(s) had a direct promoting effects on the immune system, in addition, they compete with pathogenic organisms for nutrient. In contrast, Houshmand et al. (2012) noticed no significant differences $(\mathrm{P}<0.05)$ with dietary addition of the prebiotic.

Regarding the effect of low protein diet on antibody titre against ND virus, Zeng et al. (2015) reported that, broilers fed a feed that included $16.81 \%$ or lesser CP had significantly lower ND antibody titer $(\mathrm{P}<0.05)$. Therefore, the minimum dietary $\mathrm{CP}$ requirement of broilers from 22 to 42 days of age was suggested as $17.63 \%$. In contrast Rao et al. (2011) demonstrated that, antibody titre against ND virus were not affected $(\mathrm{P}<0.05)$ by reduction in $\mathrm{CP}$.

\section{CONCLUSION}

The addition of $0.1 \%$ prebiotic to broilers fed low protein diets $(95,90$ and $85 \%$ of NRC protein requirements) has a beneficial effect on growth parameters, carcass traits and economic value without adverse effect on broiler immunity. It is both fascinating and healthy to the consumer, addition of prebiotic decreased $(\mathrm{P}<0.05)$ cholesterol, triglyceride and fat content of broiler meat (breast and thigh), while protein content of broiler breast and thigh meat significantly $(\mathrm{P}<0.05)$ increased.

\section{REFERENCES}

Abdel-Fattah, F.A. and Fararh, K.M. (2009): Effect of dietary supplementation of probiotic, prebiotic and synbiotic on performance, carcass characteristics, blood picture and some biochemical parameters in broiler chickens. Benha Vet. Med. J, 20, 9-23.

Abdel-Hafeez, H.M.; Saleh, E.S.; Tawfeek, S.S.; Youssef, I.M. and Abdel-Daim, A.S. (2017): Effects of probiotic, prebiotic, and synbiotic with and without feed restriction on performance, hematological indices and carcass characteristics of broiler chickens. Asian-Australasian journal 
of animal sciences, 30(5), 672.

Abdel-Raheem, S.M. and Abd-Allah, S.M. (2011): The effect of single or combined dietary supplementation of mannan oligosacharide and probiotics on performance and slaughter characteristics of broilers. Int. J. Poult. Sci, 10(11), 854-862.

Afrose, S.; Hossain, M.S.; Maki, T. and Tsujii, H. (2009): Karaya root saponin exerts a hypocholesterolemic response in rats fed a high-cholesterol diet. Nutrition research, 29(5), 350354.

Ajuwon, K.M. (2016): Toward a better understanding of mechanisms of probiotics and prebiotics action in poultry species. Journal of Applied Poultry Research, 25(2), 277-283.

Akhadiarto, S. (2010): Pengaruh pemberian probiotik temban, biovet dan biolacta terhadap persentase karkas, bobot lemak abdomen dan organ dalam ayam broiler. Jurnal sains dan teknologi Indonesia, 12(1).

$A O A C$ (2011): Official methods of analytical chemist. 18th ed. Gaithersburg (MA): AOAC International.

Awad, E.A.; Fadlullah, M.; Zulkifli, I.; Farjam, A.S. and Chwen, L.T. (2014): Amino acids fortification of lowprotein diet for broilers under tropical climate: ideal essential amino acids profile. Italian Journal of Animal Science, 13(2), 3166.

Ballou, C.E. (1970): A study of the immunochemistry of three yeast mannans. Journal of Biological Chemistry, 245(5), 1197-1203.

Baurhoo, B.; Ferket, P.R. and Zhao, X. (2009): Effects of diets containing different concentrations of mannanoligosaccharide or antibiotics on growth performance, intestinal development, cecal and litter microbial populations, and carcass parameters of broilers. Poultry Science, $88(11)$, 2262-2272.

Bligh, E.G. and Dyer, W.J. (1959): A rapid method of total lipid extraction and purification. Canadian journal of biochemistry and physiology, 37(8), 911-917.

Bogustawska-Tryk, M.; Piotrowska, A. and Burlikowska, K. (2012): Dietary fructans and their potential beneficial influence on health and performance parametrs in broiler chickens. Journal of Central European Agriculture, 13(2), 0-0.

Bozkurt, M.; Küçükyilmaz, K.; Catli, A.U.; Çınar, M.; Bintaş, E. and Çöven, F. (2012): Performance, egg quality, and immune response of laying hens fed diets supplemented with mannanoligosaccharide or an essential oil mixture under moderate and hot environmental conditions. Poultry science, 91(6), 1379-1386.

Chacher, M.F.A.; Kamran, Z.; Ahsan, U.; Ahmad, S.; Koutoulis, K.C.; Qutab Ud Din, H.G. and Cengiz, Ö. (2017): Use of mannan oligosaccharide in broiler diets: an overview of underlying mechanisms. World's Poultry Science Journal, 73(4), 831-844.

Chae, B.J.; Lohakare, J.D.; Moon, W.K.; Lee, S.L.; Park, Y.H. and Hahn, T.W. (2006): Effects of supplementation of $\beta$-glucan on the growth performance and immunity in broilers. Research in veterinary science, 80(3), 291-298.

Corrigan, A.; Horgan, K.; Clipson, N. and Murphy, R.A. (2011): Effect of dietary supplementation with a Saccharomyces cerevisiae mannan oligosaccharide on the bacterial community structure of broiler cecal contents. Applied and environmental microbiology, 77(18), 6653-6662.

Cox, C.M.; Stuard, L.H.; Kim, S.; McElroy, A.P.; Bedford, M.R. and Dalloul, R.A. (2010): Performance and immune responses to dietary $\beta$-glucan in broiler chicks. Poultry Science, 89(9), 19241933.

Çınar, M.; Çatlı, A.U.; Küçükyılmaz, K. and Bozkurt, M. (2009): The effect of single or combined dietary supplementation of prebiotics, organic acid and probiotics on performance and slaughter characteristics of 
broilers. South African Journal of Animal Science, 39(3).

Dehghani-Tafti, N. and Jahanian, R. (2016): Effect of supplemental organic acids on performance, carcass characteristics, and serum biochemical metabolites in broilers fed diets containing different crude protein levels. Animal Feed Science and Technology, 211, 109-116.

Fallah, R.; Kiani, A. and Azarfar, A. (2013): A review of the role of five kinds of alternatives to in-feed antibiotics in broiler production. Journal of Veterinary Medicine and Animal Health, 5(11), 317-321.

Ferket, P.R.; Santos, A.A. and Oviedorondón, E.O. (2005): Dietary factors that affect gut health and pathogen colonization.

Gadde, U.; Kim, W.H.; Oh, S.T. and Lillehoj, H.S. (2017): Alternatives to antibiotics for maximizing growth performance and feed efficiency in poultry: a review. Animal health research reviews, 18(1), 26-45.

Gao, J.; Zhang, H.J.; Yu, S.H.; Wu, S.G.; Yoon, I.; Quigley, J. and Qi, G.H. (2008): Effects of yeast culture in broiler diets on performance and immunomodulatory functions. Poultry Science, 87(7), 1377-1384.

Gheisari, H.R.; Asasi, K.; Mostafa, I. and Mohsenifard, E. (2015): Effect of different levels of dietary crude protein on growth performance, body composition of broiler chicken and low protein diet in broiler chicken. International Journal of Poultry Science, 14(5), 285.

Hai, D.T. and Blaha, J. (2000): Effect of low-protein diets adequate in levels of essential amino acids on broiler chicken performance. Czech Journal of Animal Science, 45(9), 429-436.

Hassan, R.I. and El Shoukary, R.D. (2019): Impact of dietary supplementation with cress seeds (Lepidium Sativum L.) on growth performance, carcass characteristics and behavior of broilers. Alexandria Journal for
Veterinary Sciences, 61: 38-44.

Hazrati, S.; Rezaeipour, V. and Asadzadeh, $S$. (2020): Effects of phytogenic feed additives, probiotic and mannanoligosaccharides on performance, blood metabolites, meat quality, intestinal morphology, and microbial population of Japanese quail. British poultry science, 61(2), 132-139.

Hooge, D.M.; Kiers, A.; Connolly, A.; Fasina, Y.O.; Olowo, Y.L.; Amal, O.A. and Iyayi, E.A. (2013): Meta-Analysis Summary of Broiler Chicken Trials with Dietary. International Journal of Poultry Science, 12(1), 55-63.

Houshmand, M.; Azhar, K.; Zulkifli, I.; Bejo, M.H. and Kamyab, A. (2012): "Effects of Prebiotic, Protein Level, and Stocking Density on Performance, Immunity, and Stress Indicators of Broilers." Poultry Science 91(2):393401. doi: 10.3382/ps.2010-01050.

Huang, R.L.; Deng, Z.Y.; Yang, C.B.; Yin, Y.L.; Xie, M.Y.; Wu, G.Y. and Guo, Y.M. (2007): Dietary oligochitosan supplementation enhances immune status of broilers. Journal of the Science of Food and Agriculture, 87(1), 153-159.

Huff, G.R.; Huff, W.E.; Rath, N.C. and Tellez, G. (2006): Limited treatment with b-1,3/1,6-glucan improves production values of broiler chickens challenged with Escherichia coli. Poult Sci. 85: 613-618.

Hussein, E.O.; Ahmed, S.H.; Abudabos, A.M.; Suliman, G.M.; El-Hack, A.; Mohamed, E. and $N$ Alowaimer, A. (2020): Ameliorative effects of antibiotic-, probiotic-and phytobioticsupplemented diets on the performance, intestinal health, carcass traits, and meat quality of Clostridium perfringens-infected broilers. Animals, 10(4), 669.

Ilham, I.; Nurliana, N.; Delima, M.; Sugito, S. and Samadi, S. (2019): Administration of Various Feed Additives on Cholesterol Content of Meat and Fat Abdomen of Local Chicken (Gallus domesticus). Animal 
Production, 20(1), 45-52.

Jahanian, $R$. and Ashnagar, M. (2015): Effect of dietary supplementation of mannan-oligosaccharides on performance, blood metabolites, ileal nutrient digestibility, and gut microflora in Escherichia colichallenged laying hens. Poultry science, 94(9), 2165-2172.

Kamran, Z.; Mirzaa, M.A.; Ahmad, S.; Samad, H.A.; Sohail, M.U. and Saadullahb, M. (2013): Performance of broiler chickens fed mannan oligosaccharides as alternatives to antibiotics from one to twenty-two days of age. J Anim Plant Sci, 23, 1482-1485.

Kamran, Z.; Sarwar, M.; Mahr-un-Nisa, Nadeem, M.A.; Mushtaq, T.; Ahmed, T. and Mushtaq, M.M.H. (2008): Effect of low levels of dietary protein on growth, protein utilisation and body composition of broiler chicks from one to twenty-six days of age. Avian Biology Research, 1(1), 19-25.

Kamran, Z.A.H.I.D.; Sarwar, M.U.H.A.M. M.A.D.; Nisa, M.U.; Nadeem, M.A. and Mahmood, S. (2010): Effect of low levels of dietary crude protein with constant metabolizable energy on nitrogen excretion, litter composition and blood parameters of broilers. Int. J. Agric. Biol, 12, 401-405.

Khalaji, S.; Zaghari, M. and Nezafati, S. (2011): The effects of mananoligosaccharides on caecal microbial populations, blood parameters, immune response and performance of broiler chicks under controlled condition. African Journal of Biochemistry Research 5: 160-164.

Khan, S.H. and Iqbal, J. (2016): Recent advances in the role of organic acids in poultry nutrition. Journal of applied animal research, 44(1), 359-369.

Li, X.H.; Chen, Y.P.; Cheng, Y.F.; Yang, W.L.; Wen, C. and Zhou, Y.M. (2016): Effect of yeast cell wall powder with different particle sizes on the growth performance, serum metabolites, immunity and oxidative status of broilers. Animal Feed Science and Technology, 212, 81-89.

Mahmoud, U.T. and Elsayed, M.S. (2017): Behavioral and physiological effects of mannan-oligosaccharide and $\beta$-glucan prebiotic combination on heat stressed broiler chickens. Journal of Advanced Veterinary Research, 7(3), 81-86.

Mahmoud, U.T.; Hassan, R.; Amen, O.; Abdel-Raheem, G. and AlRammamneh, D. (2020): Effect of Prebiotic on the Behavioural Patterns, Performance, Carcass Characteristics, Antibody Titer and Some Blood Parameters of Mule Ducks. SVUInternational Journal of Veterinary Sciences, 3(1), 27-38.

Marcu, A.; Văcaru-opriş, I. and Marcu, A. (2009): The influence of feed protein and energy level on meat chemical composition from different anatomical regions at "Cobb 500" Hybrid. Scientific Papers Animal Science and Biotechnologies, 42(2), 147-150.

Mehdi, A. and Hasan, G. (2012): Immune response of broiler chicks fed yeast derived mannan oligosaccharides and humate against Newcastle disease. World Applied Sciences Journal, 18(6), 779-85.

Midilli, M.U.S.T.A.F.A.; Alp, M.; Kocabach, N.; Muglah, O.H.; Turan, N.; Yilmaz, H. and Cakir, S.E.R.K.A.N. (2008): Effects of dietary probiotic and prebiotic supplementation on growth performance and serum $\operatorname{IgG}$ concentration of broilers. South African journal of animal science, 38(1), 21-27.

Naeemi, E.D.; Ahmad, N.; Al-Sharrah, T.K. and Behbahani, M. (1995): Rapid and simple method for determination of cholesterol in processed food. Journal of AoAC international, 78(6), 15221524.

N.R.C. (1994): (National Research Councile), Nutrient Requirements of poultry (9threversed edition.) National Academy press, Washington, C., USA. 
Odefemi, T.R. (2016): Performance response and carcass characteristics of broilers fed dietary antibiotics, probiotics and prebiotics. European Journal of Agriculture and Forestry Research, 4(1), 27-36.

OIE. (2013): (World Organisation for Animal Health), Manual of diagnostic tests and vaccines for terrestrial animals. $7^{\text {th }}$ ed. Paris. 1404 p.

Omar, M.; Abdel-hamid, T.; Esam, S. and Omar, A. (2019): Growth and economic performance of using dried tomato pomace for mallard ducks. Slovenian Veterinary Research, 56(22-Suppl): 699-706.

Okrathok, S. and Khempaka, S. (2020): Modified-dietary fiber from cassava pulp reduces abdominal fat and meat cholesterol contents without affecting growth performance of broiler chickens. Journal of Applied Poultry Research, 29(1), 229-239.

Ooi, L.G. and Liong, M.T. (2010): Cholesterol-lowering effects of probiotics and prebiotics: a review of in vivo and in vitro findings. International journal of molecular sciences, 11(6), 2499-2522.

Ospina-Rojas, I.C.; Murakami, A.E.; Duarte, C.R.A.; Eyng, C.; Oliveira, C.A.L. and Janeiro, V. (2014): Valine, isoleucine, arginine and glycine supplementation of low-protein diets for broiler chickens during the starter and grower phases. British Poultry Science, 55(6), 766-773.

Park, S.O. and Park, B.S. (2011): Effect of dietary microencapsulated-inulin on carcass characteristics and growth performance in broiler chickens. Journal of Animal and Veterinary Advances 10: 1342-1349.

Pourabedin, M. and Zhao, X. (2015): Prebiotics and gut microbiota in chickens. FEMS microbiology letters, 362(15), fnv122.

Rao, S.R.; Raju, M.V.L.N.; Panda, A.K.; Poonam, N.S.; Moorthy, O.K.; Srilatha, T. and Sunder, G.S. (2011):
Performance, carcass variables and immune responses in commercial broiler chicks fed graded concentrations of threonine in diet containing sub-optimal levels of protein. Animal feed science and technology, 169(3-4), 218-223.

Ravangard, A.H.; Houshmand, M.; Khajavi, M. and Naghiha, R. (2017): Performance and cecal bacteria counts of broilers fed low protein diets with and without a combination of probiotic and prebiotic. Brazilian Journal of Poultry Science, 19(SPE), 75-82.

Rehman, A.; Arif, M.; Sajjad, N.; Al-Ghadi, M.Q.; Alagawany, M.; Abd El-Hack, M.E. and Swelum, A.A. (2020): Dietary effect of probiotics and prebiotics on broiler performance, carcass, and immunity. Poultry Science, 99(12), 6946-6953.

Salehimanesh, A.; Mohammadi, M. and Roostaei-Ali Mehr, M. (2016): Effect of dietary probiotic, prebiotic and synbiotic supplementation on performance, immune responses, intestinal morphology and bacterial populations in broilers. Journal of animal physiology and animal nutrition, 100(4), 694-700.

Salianeh, N.; Shirzad, M.R. and Seifi, S. (2011): Performance and antibody response of broiler chickens fed diets containing probiotic and prebiotic. Journal of Applied Animal Research, 39(1), 65-67.

Samanta, A.K.; Jayapal, N.; Senani, S.; Kolte, A.P. and Sridhar, M. (2013): Prebiotic inulin: Useful dietary adjuncts to manipulate the livestock gut microflora. Brazilian Journal of Microbiology, 44(1), 1-14.

Shao, D.; Shen, Y.; Zhao, X.; Wang, Q.; Hu, Y.; Shi, S. and Tong, H. (2018): Lowprotein diets with balanced amino acids reduce nitrogen excretion and foot pad dermatitis without affecting the growth performance and meat quality of free-range yellow broilers. Italian Journal of Animal Science, 17(3), 698-705. 
Shendare, R.C.; Gongle, M.A.; Rajput, A.B.; Wanjari, B.V. and Mandlekar, S.M. (2008): Effect of supplementation of Manno-Oligosaccharide and b-glucans on maize based meal on commercial broilers. Veterinary World, 1(1), 13.

Sojoudi, M.R.; Dadashbeiki, M. and Bouyeh, $M$. (2012): Effect of different levels of prebiotics TechnoMos on carcass characteristics of broiler chickens. J. Basic Appl. Sci. Res, 2(7), 6778-6794.

Sutama, I.N.S.; Susila, T.O.; Lindawati, S.A.; Indrawati, R.R. and Ariana, I.T. (2010): Pengaruh penggunaan prebiotik dalam ransum terhadap profil lipid serum dan kolesterol daging ayam kampong. Majalah Ilmiah Peternakan.

Swennen, Q.; Janssens, G.P.J.; Collin, A.; Bihan-Duval, E.L.; Verbeke, K.; Decuypere, E. and Buyse, J. (2006): Diet-induced thermogenesis and glucose oxidation in broiler chickens: In- fluence of genotype and diet composition. Poult. Sci. 85:731-742.

Swennen, Q.; Janssens, G.P.J.; Millet, S.; Vansant, G.; Decuypere, E. and Buyse, $J$. (2005): Effects of substitution between fat and protein on feed intake and its regulatory mechanisms in broiler chickens: Endocrine functioning and intermediary metabolism. Poultry Science, 84(7), 1051-1057.

Taherpour, K.; Moravej, H.; Shivazad, M.; Adibmoradi, $M$. and Yakhchali, $B$. (2009): Effects of dietary probiotic, prebiotic and butyric acid glycerides on performance and serum composition in broiler chickens. African Journal of Biotechnology, 8(10).

Wang, X.; Farnell, Y.Z.; Peebles, E.D.; Kiess, A.S.; Wamsley, K.G.S. and Zhai, $W$. (2016): Effects of prebiotics, probiotics, and their combination on growth performance, small intestine morphology, and resident Lactobacillus of male broilers. Poultry science, 95(6), 1332-1340.
Weitkunat, K.; Schumann, S.; Petzke, K.J.; Blaut, M.; Loh, G. and Klaus, S. (2015): Effects of dietary inulin on bacterial growth, short-chain fatty acid production and hepatic lipid metabolism in gnotobiotic mice. The Journal of nutritional biochemistry, 26(9), 929-937.

Wijtten, P.J.A.; Prak, R.; Lemme, A. and Langhout, D.J. (2004): Effect of different dietary ideal protein concentrations on broiler performance. British Poultry Science, 45(4), 504-511.

Wiryawan, K.G.; Sriasih, M. and Winata, I.D.P. (2005): Penampilan ayam pedaging yang diberi probiotik (EM-4) sebagai pengganti antibiotik. Majalah Ilmiah Peternakan, 8(2).

Xie, M.; Jiang, Y.; Tang, J.; Wen, Z.G.; Zhang, Q.; Huang, W. and Hou, S.S. (2017): Effects of low-protein diets on growth performance and carcass yield of growing White Pekin ducks. Poultry science, 96(5), 1370-1375.

Yadav, S. and Jha, R. (2019): Strategies to modulate the intestinal microbiota and their effects on nutrient utilization, performance, and health of poultry. Journal of animal science and biotechnology, 10(1), 1-11.

Yalçinkaya, I.; Guengoer, T.; Başalan, M. and Erdem, E. (2008): Mannan oligosaccharides (MOS) from Saccharomyces cerevisiae in broilers: Effects on performance and blood biochemistry. Turkish Journal of Veterinary and Animal Sciences, 32(1), 43-48.

Yang, Y.; Iji, P.A. and Choct, M. (2009): Dietary modulation of gut microflora in broiler chickens: a review of the role of six kinds of alternatives to infeed antibiotics. World's Poultry Science Journal, 65(1), 97-114.

Zakeri, A. and Kashefi, P. (2011): The comparative effects of five growth promoters on broiler chickens humoral immunity and performance. Journal of Animal and Veterinary Advances, 10(9), 1097-1101. 
Zeng, X.; Li, X.; Hu, Y.; Wen, Q.; Zhao, L.; Zhang, L. and Luo, X. (2015): Dietary crude protein requirement of broilers from 22 to 42 days of age. Chinese Journal of Animal Nutrition, 27(8), 2534-2543.

Žikić, D.; Perić, L.; Ušćebrka, G.;
Stojanović, S.; Milić, D. and Nollet, L. (2011): Influence of dietary mannanoligosaccharides on histological parameters of the jejunal mucosa and growth performance of broiler chickens. African Journal of Biotechnology, 10(32), 6172-6176.

\section{تأثير البريبيوتيك علي الاداء والاستجابة المناعية لبداري التسمين المغذاه علي علائق منخفضة في البروتين}

\section{نجلاء صلاح خلاف ابراهيم ، عبل الباسط نصر سبل احد ، غادة شرف الدين عبد الرحيم}

E-mail: naglaasalah@vet.aun.edu.eg Assiut University web-site: www.aun.edu.eg

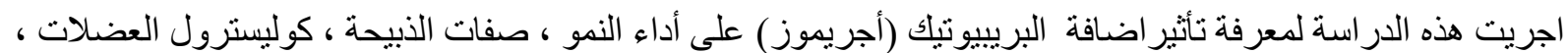

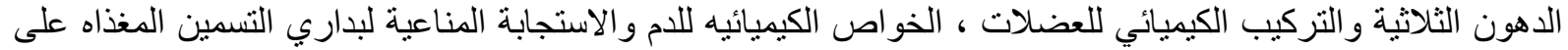

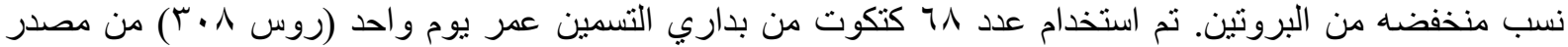

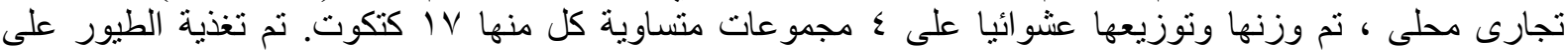

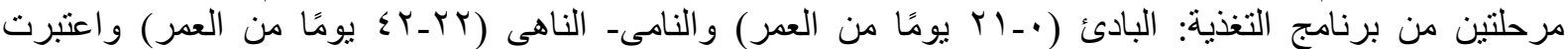

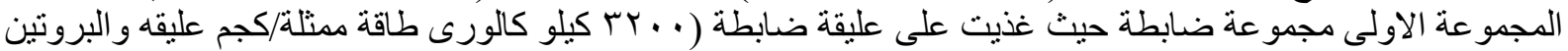

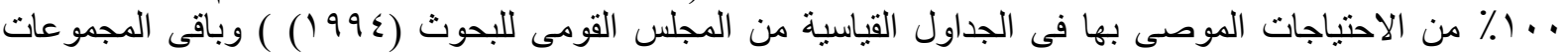

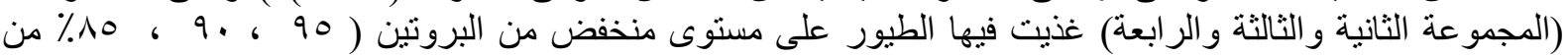

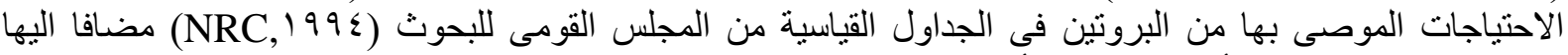

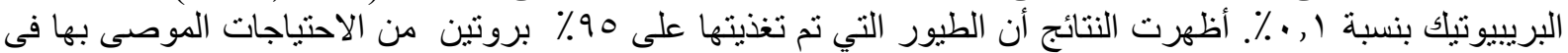

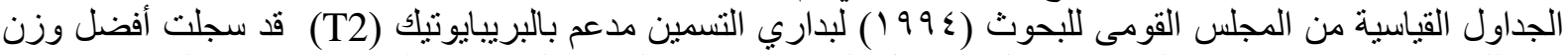

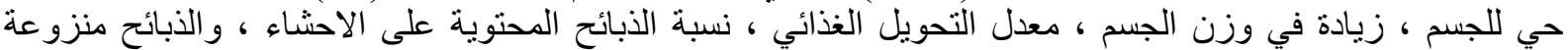

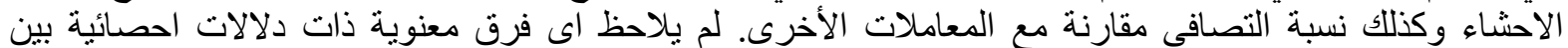

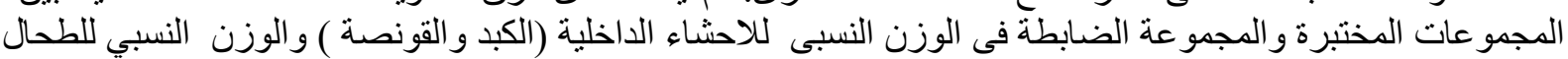

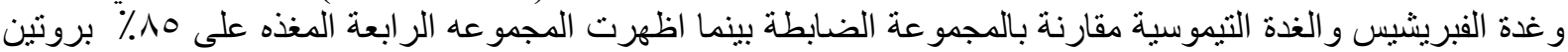

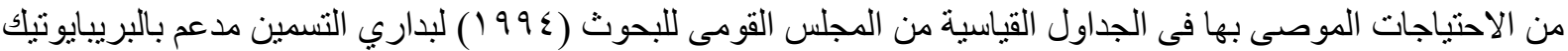

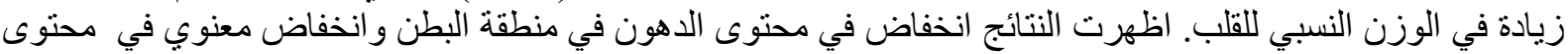

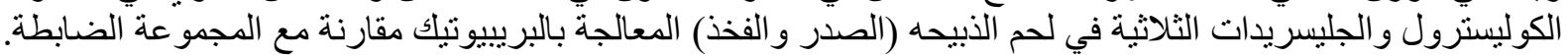

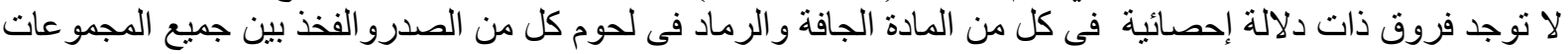

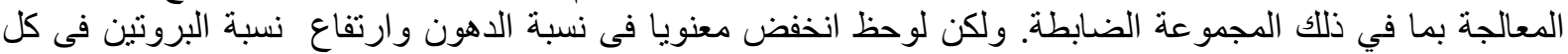

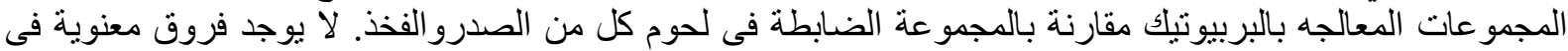

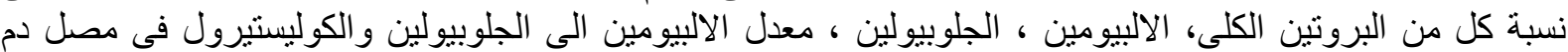

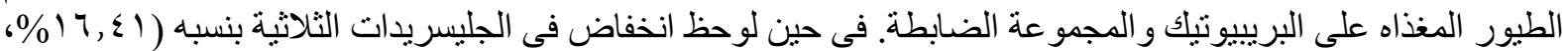

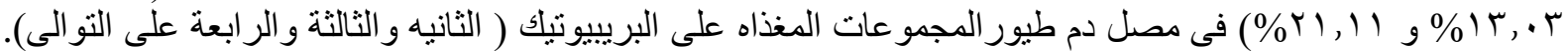

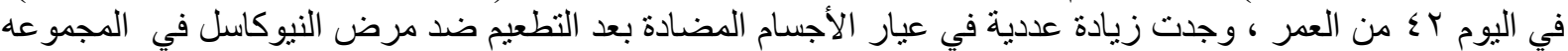

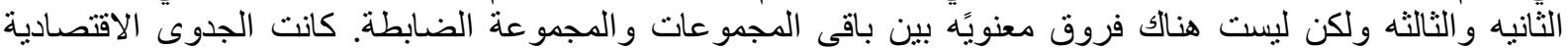

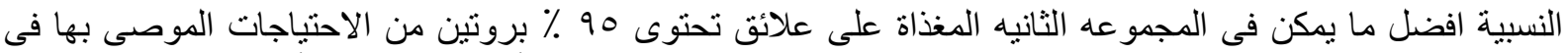

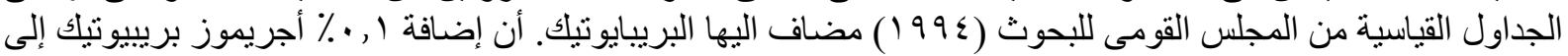

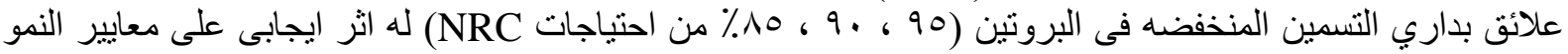

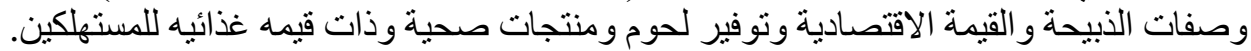

